\title{
High frequency of extra-pair copulation with low level of extra-pair fertilization in the Lanyu scops owl Otus elegans botelensis
}

\author{
Yu-Cheng Hsu, Shou-Hsien Li, Yao-Sung Lin, Mark T. Philippart and Lucia Liu Severinghaus
}

\begin{abstract}
Hsu, Y.-C., Li, S.-H., Lin, Y.-S., Philippart, M. T. and Severinghaus, L. L. 2006. High frequency of extra-pair copulation with low level of extra-pair fertilization in the Lanyu scops owl Otus elegans botelensis. - J. Avian Biol. 37: 36-40.
\end{abstract}

\begin{abstract}
The genetic mating system is known for only a few species of owls. Most of them are genetically monogamous. The Lanyu scops owl Otus elegans botelensis breeds in high density in the forests of Lanyu (Orchid Island), southeast of Taiwan. Because extra-pair copulations (EPCs) have frequently been observed, we suspected a high degree of extrapair fertilizations (EPFs). Through intensive field observations we quantified both within-pair and extra-pair copulations of this owl, and used a set of microsatellite loci to assign the parentage of 200 offspring from 108 families collected between 1999 and 2004. Among copulations for which we could identify both participants, $19.77 \%$ were EPC. However, no EPC was observed in the period just before egg laying. We found only two cases of parentage mismatch among 108 broods. The first case was most likely a case of brood usurpation, which would be the first case reported in the Strigidae. The second case was an EPF resulting in one offspring. Our study found that parentage mismatch in the Lanyu scops owls to be extremely low, therefore reproductive success can be estimated accurately by simply counting chicks in nests.
\end{abstract}

Y.-C. Hsu and Y.-S. Lin, Institute of Ecology and Evolutionary Biology, National Taiwan University, Taipei 106, Taiwan. S.-H. Li, Department of Life Science, National Taiwan Normal University, Taipei 116, Taiwan. M. T. Philippart and L. L. Severinghaus (correspondence), Research Center for Biodiversity, Academia Sinica, Taipei 115, Taiwan.E-mail: zobbowl@gate.sinica.edu.tw

The application of molecular techniques to paternity identification has shown extra-pair fertilization (EPF) to be common (e.g., Hasselquist and Sherman 2001), even though most birds are thought to be socially monogamous (Lack 1968). Many hypotheses have been proposed to explain the functions of EPF, including the avoidance of inbreeding (Blomqvist et al. 2002, Hansson et al. 2004), the elevation of offspring fitness (Jennions and Petrie 2000), and others (see review in Griffith et al. 2002).

Although common among many species of birds, EPF has previously been detected in only two of the six species of owl studied genetically. In these studies burrowing owls Athene cunicularia produced 5-10\% extra-pair young (Johnson 1993), and barn owls Tyto alba $0.5 \%$ (Roulin et al. 2004); eastern screech owls Otus asio (Lawless et al. 1997), long-eared owls Asio otus
(Marks et al. 1999), little owls Athene noctua (Müller et al. 2001), and flammulated owls Otus flammeolus (Arsenault et al. 2002) were genetically monogamous. This could be a demonstration of the phylogenetic effect (Arnold and Owens 2002), but it could also reflect the poorly studied nature of owl genetic mating systems.

Lanyu scops owl Otus elegans botelensis is found in subtropical evergreen broad-leaved forests on Lanyu (Orchid Island, $22^{\circ} \mathrm{N}, 121^{\circ} 5^{\prime} \mathrm{E}$ ). It breeds in natural tree cavities (Severinghaus 1986), and its population density in different parts of the island varies with the number of cavities present (Severinghaus et al. 2000). Each year, females begin laying eggs in late April, however, copulations have been observed as early as late November of the previous year (Severinghaus and Philippart, unpublished data). Copulation is difficult to quantify in most bird species. Lanyu scops owl males 
utter a special high-pitched call during copulation (Severinghaus 1986), which makes it possible to record the number of copulations each night. In this study, we aim to quantify the frequency of EPC and EPF in the population. We chose to study the genetic mating system of the Lanyu scops owl for several reasons: (1) it is socially monogamous but breeding densities are very high in some locations. For example, in 1994, 16 owls nested in an 1.2 ha area (calculated from Severinghaus 2000). (2) radio-tracking data have revealed that Lanyu scops owls' activity ranges overlap (Severinghaus 2000), allowing females the opportunity to interact with males other than their own mates. (3) extra-pair copulations (EPC) have been observed (Severinghaus and Philippart unpubl. data).

\section{Materials and methods}

\section{Fieldwork}

This study is part of an on-going research program that was started in 1985 by the corresponding author. During the past 20 years, a field team has conducted extensive field surveys each year, attempting to trap and color-ring as many adults and juveniles as possible. The field team has monitored nest cavity use, supplemented by observations of pairing behavior such as food provisioning and allopreening to identify breeding pairs. Lanyu scops owls appear to be indifferent to the presence of field workers. Because they are most active at $6-10 \mathrm{~m}$ above the ground (Severinghaus et al. 2000), field workers are able to read their color ring combinations through binoculars with a moderately strong spotlight.

From 1999 to 2004, we collected blood samples from each owl caught for DNA analysis, and quantified copulation events. However, because of their nocturnal habits, it was sometimes impossible to identify both members of the copulating pair. In this report, we only used records for which we saw both individuals clearly and at least one of them was color marked. We conducted paternity analyses only on those families for which we collected DNA from both parents and at least one offspring.

\section{DNA extraction and microsatellite genotyping}

From each bird captured, we collected about $20 \mu \mathrm{l}$ of blood by brachial venipuncture and preserved it in Queen's lysis buffer (Seutin et al. 1991). DNA was extracted from blood using a method modified from Gemmell and Akiyama (1996). In previous studies, we identified 18 microsatellite loci for the Lanyu scops owl (Hsu et al. 2003, 2005). All of these loci conform to Hardy-Weinberg expectations, and no detectable linkage disequilibrium was found among them. Herein, we used
12 of them as genetic markers for parentage analysis and heterozygosity estimation (locus names: Oe022, Oe029, Oe045, Oe053, Oe081, Oe085, Oe128, Oe129, Oe142, Oe149, Oe171, and Oe3-7). We used the polymerase chain reaction (PCR) to amplify the microsatellites for each individual. The forward primer of each locus was labelled with HEX, FAM, or TAMRA fluorescent dye. Detailed information about the primer sequences, repeat motifs of the microsatellite loci, GenBank accession numbers, and PCR protocols can be found in Hsu et al. (2003, 2005). We conducted PCR using an iCycler thermal cycler (Bio-Rad). The PCR products were electrophoresed on a MegaBACE 1000 autosequencer (Amersham Biosciences). We analyzed the sizes of the alleles with Genetic Proflier 2.0 software (Amersham Biosciences).

\section{Parentage analysis}

We assigned the parentage of an offspring to its social parents when its microsatellite alleles matched those of the breeding pair. For offspring whose genotype contained at least two loci not matching the genotype of their social parents, we used the CERVUS program (Marshall et al. 1998) to identify the most-likely parents, using all genotyped adults as potential candidates.

\section{Results}

\section{Lanyu scops owl copulations}

From 2000 to 2003, we counted 854 copulations between January and June. More copulations took place in March and April than the other months (on average 1.34 times and 1.45 times per hour of observation respectively). Between 1999 and 2004, we observed 177 copulations for which we could identify both participants (95 females and 83 males). Among these, 35 (19.77\%) were EPCs involving 25 females and 23 males (Table 1). The general pattern of EPCs was for a male or female to repeatedly copulate with the same extra-pair partner in the same year, but often switch extra-pair partners in different years. Sometimes both members of a pair conducted EPCs in the same season. Yet when a pair which had copulated with other owls switched mates in a subsequent year, they often continue to copulate with each other after each formed pairs with another bird. For example, one female copulated with her exmate while paired with a new male in 2001, she then paired with a new male in 2002 while continuing to copulate with her ex-mate of 2001. Only one female was seen to copulate with two extra-pair males within the same year.

All observed EPCs occurred early in the breeding season, and the frequency of EPCs decreased with time 
Table 1. Number of copulations recorded in the Lanyu scops owl.

\begin{tabular}{|c|c|c|c|c|}
\hline $\begin{array}{l}\text { (A) By year } \\
\text { Year }\end{array}$ & No. of copulations & No. of WPCs* & No. of EPCs** & \\
\hline $\begin{array}{l}1999 \\
2000 \\
2001 \\
2002 \\
2003 \\
2004 \\
\text { Total }\end{array}$ & $\begin{array}{r}27 \\
50 \\
26 \\
26 \\
27 \\
21 \\
177\end{array}$ & $\begin{array}{r}22 \\
39 \\
19 \\
24 \\
22 \\
16 \\
142\end{array}$ & $\begin{array}{r}5 \\
11 \\
7 \\
2 \\
5 \\
5 \\
35\end{array}$ & \\
\hline $\begin{array}{l}\text { (B) By month } \\
\text { Month }\end{array}$ & No. of copulations & No. of WPCs & No. of EPCs & $\%$ of EPCs \\
\hline $\begin{array}{l}\text { December } \\
\text { January } \\
\text { February } \\
\text { March } \\
\text { April } \\
\text { May } \\
\text { June } \\
\text { July } \\
\text { August November } \\
\text { Total }\end{array}$ & $\begin{array}{r}2 \\
14 \\
35 \\
42 \\
38 \\
29 \\
16 \\
1 \\
0 \\
177\end{array}$ & $\begin{array}{r}0 \\
4 \\
20 \\
35 \\
38 \\
29 \\
16 \\
0 \\
0 \\
142\end{array}$ & $\begin{array}{r}2 \\
10 \\
15 \\
7 \\
0 \\
0 \\
0 \\
1 \\
0 \\
35\end{array}$ & $\begin{array}{c}100 \\
71.43 \\
42.86 \\
16.67 \\
0 \\
0 \\
0 \\
100 \\
0 \\
19.77\end{array}$ \\
\hline
\end{tabular}

* Within-pair copulations. ** Extra-pair copulations.

(Table 1). No EPCs were observed in April or May, the period just before egg laying. Only one case was observed in July. There was no difference in the frequency of EPCs between study sites on Lanyu $\left(\chi^{2}\right.$ test, $\mathrm{P}=0.83$ ).

\section{Paternity analysis}

In total, we analyzed the microsatellite genotypes of 541 individual owls. These included the genotypes of both parents and at least one offspring for 108 families (a total of 308 individuals: 56 males, 52 females and 200 young). Twelve of the young ( 7 males and 5 females) later bred as adults. Only five of the 108 families bred in artificial nest boxes, the others bred in natural tree cavities.

Forty-six of these families $(42.59 \%)$ including 80 offspring came from the 2.15 ha high-breeding-density study site described in $\mathrm{Wu}$ (2001). The average breeding density in this region was $8.14 \pm 1.58 \mathrm{pair} / \mathrm{ha} / \mathrm{year}$ between 1999 and 2004. The remaining families were collected from other study sites around the island.

We randomly selected 120 adults with unknown relationships from the 541 owls, and using the CERVUS program (Marshall et al. 1998) we calculated the power to exclude a false parent when neither of the parents was known. We found the exclusion power to be greater than 0.99 .

Paternity analyses found that the genotypes of 179 offspring $(89.5 \%)$ perfectly matched that of their social parents across all loci. Eighteen offspring (9\%) had either one repeat unit longer or shorter than the allele of their social parents in only one locus, and these 18 onelocus mismatch events occurred in nine of the 12 loci. We found no adult whose genotypes perfectly matched those of these 18 young. We thus regarded these mismatches as caused by mutation and assigned the paternity of these young to their social parents.

We identified three nestlings from two clutches as being illegitimate. The first case involved two young from a brood of four in cavity no. 24 in 1999. The genotype profile of this family showed that only two of the four juveniles were related to their social parents. The female whose genotype matched those of the two illegitimate offspring across all 12 microsatellite loci was an owl that bred in a neighboring cavity (no. 25). This potential genetic mother paired with a male and successfully raised a young that year. We do not have any DNA sample of her mate so we cannot be certain if he sired the two illegitimate offspring. However, by comparing the genotype of this neighboring pair's own young with those of the two illegitimate offspring, we cannot rule out the possibility that they were full siblings. In fact, this neighboring pair had actually bred in cavity no. 24 in 1998. At the date of banding, the two illegitimate young in cavity no. 24 were heavier than the two within-pair young (107 $\mathrm{g}$ and $103 \mathrm{~g}$ vs. $99 \mathrm{~g}$ and $92 \mathrm{~g}$ ). The young of cavity no. 25 fledged at least ten days later than the two illegitimate young in cavity no. 24. This means that the two illegitimate young were the oldest among the five owlets of cavity no. 24 and no. 25 .

The second case occurred in 2001. The genotype profile of the offspring matched that of its social mother, but not that of its social father. Since our field crew monitored this pair throughout the breeding season, we are certain that the female did not change mates during the breeding season. This indicated that this juvenile was sired via EPF. After screening the genotypes of all birds we collected, we found only one male whose genotype 
matched that of the juvenile across all 12 microsatellite loci and could possibly be the genetic father of this offspring. Although this male was not seen in 2001, it had been seen near that nest cavity in 2000, and it had bred in the same cavity with another female in 1999. It seems possible that after losing its nest cavity, this male extra-pair-copulated with the new female occupying this cavity and produced an EPY.

\section{Discussion}

In this study, we discovered that Lanyu scops owls had a high frequency of EPC $(19.77 \%)$, but very low proportion of EPF $(0.5 \%)$, and are essentially genetically monogamous. The situation of cavity no. 24 in 1999 suggests that two pairs of owls laid two eggs each in the same cavity. Then one pair was either forced to leave or left that cavity for unknown reasons, abandoning the two eggs to the remaining pair, before producing another brood in a neighboring cavity. The remaining pair apparently adopted the two eggs and raised the subsequent young to fledging, consequently this was not a case of EPF.

The level of EPC in Lanyu scops owls is high compared to the sole case reported for flammulated owls (Reynolds 1990). The timing of EPCs in Lanyu scops owls is quite different from the timing of EPCs in most other bird species (Birkhead and Møller 1992). Most Lanyu scops owls laid eggs in May (Severinghaus unpubl. data) while none of the observed EPCs occurred in the presumed female fertile period. It is possible that we missed some EPCs because of the difficulties involved in making observations at night, but it is highly unlikely that we missed every one of them if they did occur in April and May. Birds usually pursue EPCs for resource and or genetic benefits (Birkhead and Møller 1992, Ligon 1999), but these benefits do not seem to exist for the Lanyu scops owl. These owls do not appear to pursue EPC for genetic benefits, since no EPCs occurred during the female's fertile period. Male owls were not observed to present food to females in exchange for copulation. At present, we know of no other types of resource benefits female owls could gain through EPC. Given the fact that EPC did not occur just before egglaying period, the observed EPC behavior might serve a different purpose other than pursuing EPF, such as avoidance of aggression from other males (e.g. forced EPC in Anas bahamensis, Sorenson 1994), or evaluation of potential mates (e.g. in Haematopus ostralegus, Heg et al. 1993).

The relationships between the occurrence of EPFs and demographic factors in birds have been extensively discussed (see Arnold and Owens 2002, Griffith et al. 2002, Westneat and Stewart 2003, Neudorf 2004). Bennet and Owens (2002) claimed that a high rate of
EPFs should be associated with little need for parental care and low adult survivorship. Young Lanyu scops owls rely entirely on parental provisioning even after they fledge, and the survivorship of adult owls is as high as $75 \%$ (Severinghaus and Rothery 2001). Our findings are consistent with Bennet and Owens' conclusions.

In the case of mixed parentage in one nest, we cannot rule out the possibility of intraspecific brood parasitism (ISBP). If it was a case of ISBP, it would be the first record in owls. ISBPs are far less widespread than EPF in birds. Bennet and Owens (2002) found no ISBP in over $80 \%$ of bird species that were examined with molecular techniques. Yom-Tov (2001) listed 234 species of birds in which ISBP existed, but no owl was on that list. We believe the mixed parentage we found was more likely a case of usurpation, in which case the second pair probably chased away the first pair and adopted the eggs. Since 1985, we found four cases where two pairs of owls nested in the same cavity (Severinghaus 1992, unpubl. data). Unfortunately we do not have DNA samples from these owls and their offspring to do genetic analyses.

In conclusion, although the population had a high frequency of EPCs, the low incidence of paternity mismatches (1.5\% of all offspring analyzed) suggested that this owl was genetically monogamous. Thus field monitoring alone is sufficient to provide a reliable estimate of their individual breeding success.

Acknowledgements - We thank the Science Editor of JAB, D. Tome and one anonymous reviewer for helpful comments. We also thank all members of the Lanyu scops owl research team of AS for their hard work in the field. Members of the Genetic Diversity Laboratory of NTNU provided valuable help in the lab work. This work was funded by the National Science Council to LLS and by the Council of Agriculture to SHL.

\section{References}

Arnold, K. E. and Owens, I. P. F. 2002. Extra-pair paternity and egg dumping in birds: life history, parental care and the risk of retaliation. - Proc. R. Soc. B 269: 1263-1269.

Arsenault, D. P., Stacey, P. B. and Hoelzer, G. A. 2002. No extra-pair fertilization in flammulated owls despite aggregated nesting. - Condor 104: 197-201.

Bennett, P. M. and Owens, I. P. F. 2002. Evolutionary ecology of birds. - Oxford University Press, New York, pp. 77-129.

Birkhead, T. R. and Møller, A. P. 1992. Sperm competition in birds. - Academic Press, San Diego, pp. 103-116.

Blomqvist, D., Andersson, M., Küpper, C., Cuthill, I., Kis, J., Lanctot, R. B., Sandercock, B. K., Székely, T., Wallander, J. and Kempenaers, B. 2002. Genetic similarity between mates and extra-pair parentage in three species of waders. - Nature 419: 613-615.

Gemmell, N. J. and Akiyama, S. 1996. An efficient method for the extraction of DNA from vertebrate tissues. - Trends Genet. 12: $338-339$.

Griffith, S. C., Owens, I. P. F. and Thuman, K. A. 2002. Extra pair paternity in birds: a review of interspecific variation and adaptive function. - Mol. Ecol. 11: 2195-2212. 
Hansson, B., Hasselquist, D. and Bensch, S. 2004. Do female great reed warblers seek extra-pair fertilizations to avoid inbreeding? - Proc. R. Soc. B (Suppl.) 271: S290-292.

Hasselquist, D. and Sherman, P. W. 2001. Social mating systems and extrapair fertilizations in passerine birds. - Behav. Ecol. 12: 457-466.

Heg, D., Ens, B. J., Burke, T., Jenkins, L. and Kruijt, J. P. 1993. Why does the typically monogamous oystercatcher (Haematopus ostralegus) engage in extra-pair copulations? - Behaviour 126: 247-289.

Hsu, Y.-C., Li, S.-H., Lin, Y.-S. and Severinghaus, L. L. 2005. Microsatellite loci from Lanyu scops owl (Otus elegans botelensis) and their cross-species application in four species of Strigidae. - Conserv. Genet. in press.

Hsu, Y.-C., Severinghaus, L. L., Lin, Y.-S. and Li, S.-H. 2003. Isolation and characterization of microsatellite DNA markers from the Lanyu scops owl (Otus elegans botelensis). - Mol. Ecol. Notes 3: 595-597.

Jennions, M. D. and Petrie, M. 2000. Why do females mate multiply? A review of the genetic benefits. - Biol. Rev. 75: $21-64$.

Johnson, B. S. 1993. Reproductive success, relatedness, and mating patterns in a colonial bird, the burrowing owl. - J. Raptor Res. 27: 61.

Lack, D. 1968. Ecological adaptations for breeding in birds. - Metheun and Co., London.

Lawless, S. G., Ritchison, G., Klatt, P. H. and Westneat, D. F. 1997. The mating strategies of eastern screech owls: a genetic analysis. - Condor 99: 213-217.

Ligon, J. D. 1999. Extra-pair copulations and their evolutionary significance. - In: Ligon, J. D. (ed.). The evolution of avian breeding systems. Oxford University Press, New York, pp. 287-311.

Marks, J. S., Dickinson, J. L. and Haydock, J. 1999. Genetic monogamy in long-eared owls. - Condor 101: 854-859.

Marshall, T. C., Slate, J., Kruuk, L. E. B. and Pemberton, J. M. 1998. Statistical confidence for likelihood-based paternity inference in natural populations. - Mol. Ecol. 7: 639-655.

Müller, W., Epplen, J. T. and Lubjuhn, T. 2001. Genetic paternity analysis in little owls (Athene noctua): does the high rate of paternal care select against extra-pair young? - J. Ornithol. 142: 195-203.

Neudorf, D. L. H. 2004. Extrapair paternity in birds: understanding variation among species. - Auk 121: 302-307.

Reynolds, R. 1990. Extra-pair copulation and extra-range movements in flammulated owls. - Ornis Scand. 21: 74-77.
Roulin, A., Müller, W., Sasvári, L., Dijkstra, C., Ducrest, A.-L., Riols, C., Wink, M. and Lubjuhn, T. 2004. Extra-pair paternity, testes size and testosterone level in relation to colour polymorphism in the barn owl Tyto alba. - J. Avian Biol. 35: 492-500.

Seutin, G., White, B. N. and Boag, P. 1991. Preservation of avian blood and tissue samples for DNA analysis. - Can. J. Zool. 69: $82-90$

Severinghaus, L. L. 1986. The ecology and behavior of the Lanyu scops owl (Otus elegans botelensis). - Council of Agriculture. 63p. (In Chinese)

Severinghaus, L. L. 1992. Monitoring the population of the endangered Lanyu scops owl (Otus elegans botelensis). - In: McCullough, D. R. and Barrett, R. H. (eds). Wildlife 2001: populations. Elsevier Science Publishers, Ltd., London, pp. $790-802$.

Severinghaus, L. L. 2000. Territoriality and the significance of calling in the Lanyu scops owl Otus elegans botelensis. - Ibis 142: $297-304$

Severinghaus, L. L. and Rothery, P. 2001. The survival rate of Lanyu scops owls Otus elegans botelensis. - Ibis 143: 540546.

Severinghaus, L. L., Yang, M. M., Yang, J. T., Sun, I. F. and Hsieh, T. H. 2000. The biodiversity of Lanyu forest ecosystem. - In: Chow, Y.-S., Hsieh, F. K., Wu, S.-H. and Chou, W-H. (eds). Proc. 2000 Cross-strait Symp. Biodiv. Cons., National Museum of Natural Science, Taichung, pp. 71-79. (In Chinese)

Sorenson, L. G. 1994. Forced extra-pair copulation in the whitecheeked pintail: male tactics and female responses. - Condor 96: 400-410.

Westneat, D. F. and Stewart, I. R. K. 2003. Extra-pair paternity in birds: causes, correlates, and conflict. - Ann. Rev. Ecol. Syst. 34: 365-396.

$\mathrm{Wu}$, T. Y. 2001. Nest-site selection of Lanyu scops owl (Otus elegans botelensis). - Master's thesis, National Taiwan University, Taipei, Taiwan. (in Chinese)

Yom-Tov, Y. 2001. An updated list and some comments on the occurrence of intraspecific nest parasitism in birds. - Ibis 143: $133-143$.

(Received 18 April 2005, revised 8 September 2005, accepted 12 September 2005.) 